UDC 629.439

DOI 10.17816/transsyst20184273-91

(C) K. K. Kim

Emperor Alexander I St. Petersburg State Transport University

(Saint-Petersburg, Russia)

\title{
THE RUSSIAN VERSION OF THE TRANSPORT SYSTEM "HYPERLOOP"
}

\begin{abstract}
Aim: development of the Russian version of the high-speed transport system "Hyperloop" characterized by improved technical and economic indicators.

Methods: We use the method of perforating the shell of the head part of the passenger capsule is used, the movement of which is carried out by a linear electric motor with a stator winding located on the pipe.

Results: As the research showed at a speed of about $500 \mathrm{~km} / \mathrm{h}$ for the creation of vacuum we will spend more energy than overcoming the friction of the capsule on air. Therefore the density of air in the pipe can be lowered only by 1.5-2 times.

Conclusion: The construction of the vacuum-levitating transport in Russia is reasonable and justified economically but only among the densely populated centers, i.e. mainly in the European part of Russia.
\end{abstract}

Keywords: pipe, capsule, edge air flow, turbulent spots, perforated frontal part, suction.

\section{(C) К. К. Ким}

Петербургский государственный университет путей сообщения Императора Александра I

(Санкт-Петербург, Россия)

\section{РОССИЙСКИЙ ВАРИАНТ ТРАНСПОРТНОЙ СИСТЕМЫ HYPERLOOP}

Цель: Разработка российского варианта высокоскоростной транспортной системы Hyperloop, характеризующейся улучшенными технико-экономическими свойствами.

Методы: Использовался метод перфоририрования обшивки головной части пассажирской капсулы, движение которой осуществляется с помощью линейного электрического двигателя со статорной обмоткой, расположенной на трубе.

Результаты. Установлено, что при скорости около 500 км/ч для создания вакуума тратится больше энергии, чем на преодоление трения капсулы в разреженном воздухе. По этой причине давление воздуха в трубе может быть рекомендовано в 1,5-2 раза ниже атмосферного давления.

Заключение: Создание такого транспорта в России целесообразно и экономически обосновано только между мегаполисами с высокой плотностью населения, т. е. главным образом в Европейской части России.

Ключевые слова: труба, капсула, пограничный воздушный поток, пятна турбулентности, перфорированная головная часть, отсасывание. 


\section{INTRODUCTION}

Nowadays we watch a revival of interest to the idea of the vacuum transport. It is supposed that the passenger capsules move with a speed of $500-1000 \mathrm{~km} / \mathrm{h}$ in the pipe which has vacuum. The technical vacuum stipulates a very low aerodynamic resistance on the capsule movement. It affects the required power of the drive motors, in most cases, the linear induction motors. The large speeds of movement determine the transition from the mechanical pair of rail - wheel to the magnetic suspension of the capsule. The limitation caused with the minimizing of the pipe volume where you want to create vacuum and the desire to maximize the pipe cross section which determines the throughput of this system will necessarily lead to the minimum clearances between the outer surface of the capsule and the inner surface of the pipe. In this connection it is also reasonable the keeping of the capsule in the lateral coordinate to carry out by the forces of the electromagnetic field.

The objective of the research described in this paper was the developing of a compromise variant of the high-speed pipeline transport system without using the technical vacuum but with using the rarefied air in the pipe and the drive linear induction motor.

To achieve this objective we solved the following problems:

- to prove the suitability of using this transport system in Russia;

- to work out the method of lowering the head aerodynamic resistance of the moving capsule;

- to work out the engineering calculation method of the linear induction motor.

\section{IMPLEMENTATION OF THE PROJECT OF THE VACUUM TRANSPORT IN RUSSIA}

Let's analyze the profitability of this project based on the example of the building of the road between Moscow and St. Petersburg with the length of $634.14 \mathrm{~km}$. This distance is 79.25 times more than the eight kilometer test track of the valley Quay, which costs 150 million \$. Therefore the cost of the road between Moscow and St. Petersburg is 11 billion and 185 million \$.

When $1 \$$ is equal to 65 rubles, the cost of the road between Moscow and St. Petersburg will be 722 billion rubles. Taking the inflation into account this cost will reach 853 billion rubles.

As the ticket price between Los Angeles and San Francisco (the distance between them is $600 \mathrm{~km}$ ) is planned $20 \$$ that less than one-third of the ticket price of the Russian "Sapsan" at the same distance, therefore the ticket price in Russia will be 700 rubles.

We proceed from the fact that the safe passenger density during the test of the track "Transportation Technologies" (the project "Hyperloop") will be approximately 3400 passengers per hour, i.e. the annual volume will exceed 24 
million people, it will amount to 16 billion rubles per year (24 million $\times 700$ rubles).

Therefore, the payback period of the road is equal to 53 years ( 853 billion rubles /16 billion rubles) not taking into account the profits from the sale of surplus energy.

53 years is a very long time therefore it is advisable to increase the ticket price up to 1300 rubles that corresponds to the minimum ticket price of "Sapsan" then the price of the sold tickets is equal to 31 billion rubles per year (24 million people $\times 1300$ rubles).

In this case the road will payback for 27 years.

Let's note that formerly we didn't take into account the profit on the sale of surplus energy. As the senior Director of Hyperloop project says they plan to gain 25 million $\$$ annually from the sale of surplus energy. In rubles the receipts from the sale of energy will reach 1.5 billion per year, and it will be 40 billion rubles for 27 years. Because of this the payback period drops to 25 years. This aspect requires a further analysis due to the difference in the solar activity in California and Russia.

It should be noted that we don't consider the expenditure for the technical service of the road and capsules in this paper.

In order to compare it, let's consider the high-speed communication between Moscow and St. Petersburg.

The "Russian Railways" and "Siemens" signed the first contract in May 2006. The price of eight trains "Sapsan" was 276 million $€$, besides the "Russian Railways" also signed the 30-year contract for their technical service with the German concern (354,1 million $€$ ). Then the "Russian Railways" signed a firm contract with the German "Siemens" to deliver eight more high-speed trains "Sapsan". Their price and the expenditure of technical service amounted 600 million $€$ which amounts 58 billion in the ruble equivalent.

Let's note that a separate high-speed line hasn't been built for "Sapsan" so the pass of more high-speed passenger trains demanded the removal of freight trains, it led either to the impossibility of their formation and the failure to remove the goods or to move them by a circuitous route. In this regard there is a need to build a separate high-speed line.

The cost of the planned road of the high speed railway "Nizhny Novgorod - Moscow" (its length is $400 \mathrm{~km}$ ) will be 300 billion rubles by the preliminary calculations. We didn't take into consideration the costs of pulling down the buildings and payment of compensation for them, the rent of land, carry of infrastructure, etc. Approximately it may cost another 200 billion. As a result the cost of the building will be about 500 billion rubles. If we take the inflation and "misuse expenses" into consideration it will increase by 200 billion and it will be $\sim 700$ billion. 
The distance between St. Petersburg and Moscow in a straight line is 650 $\mathrm{km}$, it is by 1.62 times more than to Nizhny Novgorod. Therefore, at the linearly dependence of the building expenditures on the distance between Moscow and St. Petersburg the building of this road will cost 1.1 trillion rubles.

Let's take the expenditures of contracts with "Siemens" into account we will receive 1.158 trillion rubles.

The average ticket price on "Sapsan" is equal to 2000 rubles. If we suppose that the passenger traffic is 7 million people per year, in rubles it will give 14 billion rubles per year ( 7 million $\times 2000$ rubles) and the payback period is $\sim 83$ years (1.158 trillion rubles /14 billion rubles).

It should be noted that the main economic factor of passenger transport is increasing the mobility of the population. If the "Sapsan" speed is $250 \mathrm{~km} / \mathrm{h}$, the capsule in the pipe is capable to speed up to $1200 \mathrm{~km} / \mathrm{h}$ but we can suppose that its maximum speed will be limited by a more modest value of $500-700 \mathrm{~km} / \mathrm{h}$. But even in this case the building of the pipeline vacuum transport in Russia is also justified but only between densely populated centers, i.e. in the European part of Russia even if we don't to build separate roads for a high-speed movement as we see at this moment.

\section{THE DEVELOPMENT OF THE UNIVERSITY}

The question arises about the expediency of creating and maintaining a technical vacuum in the pipe. As the research showed: at a speed of about 500 $\mathrm{km} / \mathrm{h}$ for the creation of vacuum we will spend more energy than overcoming the friction of the capsule on air. Therefore, the density of air in the pipe can be lowered only by $1.5-2$. However, there are questions connected with the interaction of moving capsules with the oncoming air flow.

The pattern of flow around a two-piece capsule with the dimensions of the "Sapsan" by oncoming air flow at a speed of $600 \mathrm{~km} / \mathrm{h}$ is shown in Fig. 1. At the movement of the capsule a boundary layer of air is formed on its surface. The causes of different kinds: the body surface roughness, the non-uniform of the flow of an air layer, the body vibration cause the appearance of small perturbations of the boundary layer. These perturbations lead to the appearance of turbulent spots which further convert the whole boundary layer practically into a turbulent condition that causes a sharp increasing of the aerodynamic drag of the capsule, the appearance of disturbing forces and moments acting on the capsule. If you do not struggle against this phenomenon you should increase the power of the drive motors and other devices which carry out the spatial magnetic keeping of the capsule, strengthen the capsule design, this aggravates their weight and dimension indicators. 


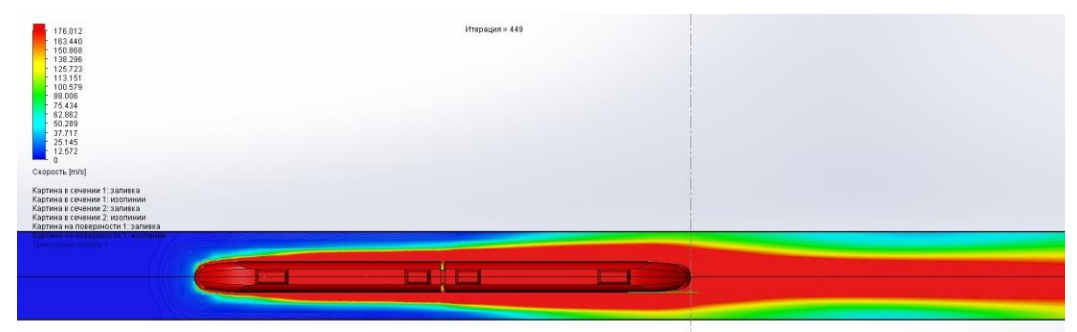

$L$

Fig. 1. The pattern of flow around a two-piece capsule with the dimensions of the "Sapsan" at a speed of $600 \mathrm{~km} / \mathrm{h}$

As we propose in $[1,2]$ it is possible to avoid partially the consequences of turbulences of the air boundary layer if we make the capsule front part perforated (Fig. 2). The suction of incipient turbulent spots of the air boundary layer is carried out through the holes (the hole diameter is 100 microns, the distance between the adjacent holes is $0.7-1 \mathrm{~mm}$ ) in the front part, owing to it the air boundary layer mainly keeps a laminar character. It can lead to reducing the aerodynamic drag up to $30 \%$. The air flow which passed through the perforated holes is used to condition and cool the current-carrying elements of the capsule. The suction can be also carried out forcibly by means of pumps [3-5].

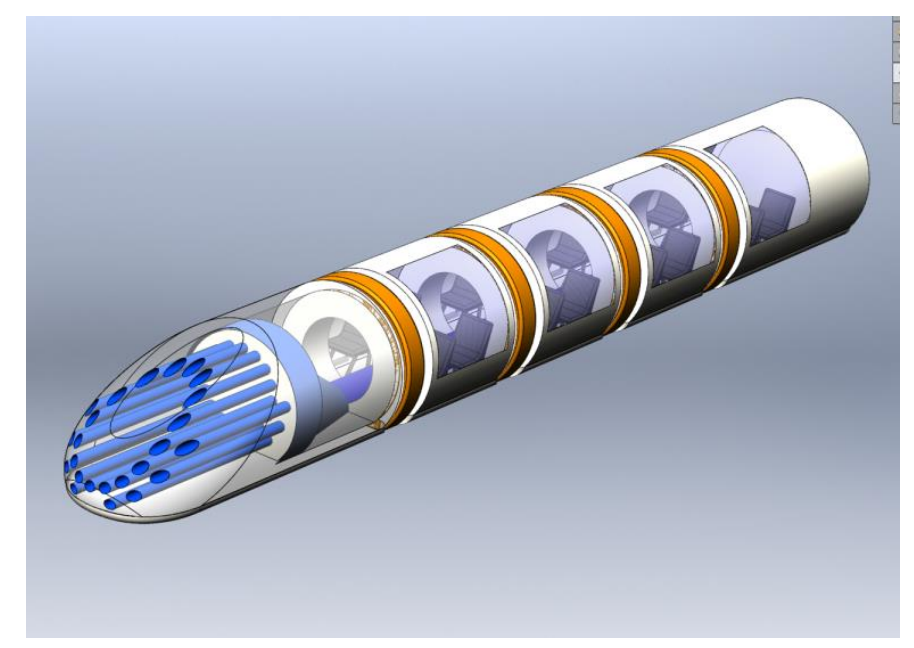

Fig. 2. The capsule with the perforated front part

One of the main units of the considered transport system is a traction linear induction motor with the one-sided stator. But where to place this stator? When we place it on the capsule the mass and dimensions are increased. Besides it is necessary to place a power source in it too as the traditional current collection is impossible at such speeds. We can avoid it if the stator is placed on the pipe along the whole length. However, in this case the cost of the pipe is 
significantly increased. Nevertheless, this question was solved in favor of the location of the stator on the pipe.

In the proposed variant of the transport system the capsule mass is relatively small as it consists only of the mass of the body and the currentcarrying elements placed on it (the mass of passengers is not taken into account).

One of the variants of the transport system with a stator located on the pipe is shown in Fig. 3. Stator 2 of the linear motor is rigidly fixed on the inner surface of pipe 1 made of ferromagnetic material. The stator has concentrated inductor winding 3 and distributed three-phase winding 4 . There is a system of short-circuited turns 6 on capsule 5. Stator 2 of the linear motor consists of electrically unconnected separate sections (segments). The beginning and end of the segment are shown by the dashed lines. All the segments are made similarly: inductor winding 3 is in the beginning segment, then three-phase winding 4 starts. The pole pitch $(\tau)$ of three-phase winding 4 is equal to the distance $(\tau)$ between adjacent short-circuited turns 6 .

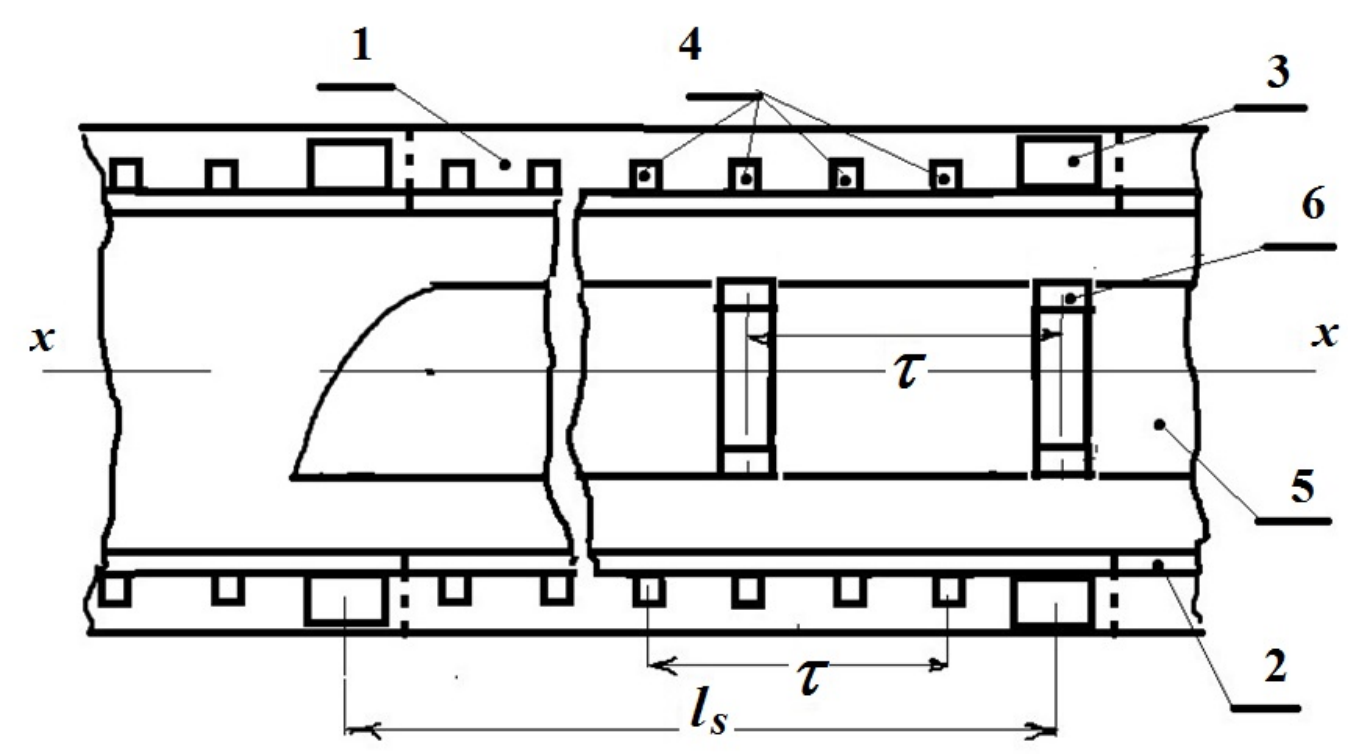

direction of movement

Fig. 3. The scheme of the transport system

The duration of the operation of any of the stator segment is equal to the period of time during which capsule 5 is within this segment. At this time period inductor winding 3 and three-phase winding 4 are fed by the power sources of the single-phase and three-phase sinusoidal current with the period $T=2 \tau / \nu$, where $v$ is the local speed of capsule 5. The power sources are not shown in Fig. 2. The current of inductor winding 3 is synchronized with the position of short-circuited turn 6 so that it reached the maximum value when the middle planes of inductor winding 3 and short-circuited turn 6 coincide. In this regard, 
the directions of the currents induced in short-circuited turns 6 by the magnetic field of inductor winding 3 are alternated. It leads to the fact that the magnetic field of these currents is distributed along the $x$-axis periodically with the period $2 \tau$. The main harmonic of this field can be considered as the field excitation. The length of the segment $\left(l_{s}\right)$ should be such in order the decreasing of the field excitation on the length $l_{s}$ was not too substantial, e.g., twice.

The frequency of current through three-phase winding 4 is strictly corresponded to the local speed of capsule 5. Therefore the speed of the running magnetic field of stator 2 with the spatial period equaled to $2 \tau$ and the speed of the field excitation are the same but these fields are shifted by the angle $\delta<\pi / 2$ determined by the value of power consumed from the power source of the threephase current [6-10].

The magnitude of the propulsive force is equal

$$
F=3 U E /(X v) \sin \delta,
$$

where $U$ and $E$ is the voltage and the EMF excitation of the segment of the three-phase winding, $X$ is the phase inductive impedance of the segment of the three-phase winding taking into consideration the mutual induction with the other two phases.

In this variant of the transport system the capsule mass is relatively small because it is determined only by the mass of body and the mass of shortcircuited turns placed on it.

As the scientific research are shown that the spindle-shaped form leads to the possibility of the capsule rotation relatively to the longitudinal axis. In order to avoid it we proposed a capsule design with the flat bottom. In addition to the stability of the movement this constructive solution allows to use a screen effect for the aerodynamic levitation of the capsule. The flat bottom leads to a more simple fabrication technology and operation of the transport system. Here we use the linear induction motor (LIM) with a one-sided stator as the drive motor. And the capsule bottom made of the electrical conductive material plays a role of the LIM runner. The stator is located opposite to the capsule bottom (on the pipe bottom). In spite of the low power characteristics LIM is one of the simplest constructive solutions for the transport systems of such type. We can carry out the levitation relatively simply using the well-known methods of magnetic suspension in the constructions with a one-sided stator. We can use the normal (perpendicular to the propulsive force) electromagnetic force arising in the LIM and it can reach a considerable value. That's why further we shall discuss some basic properties of the LIM with the one-sided stator. To increase the effectiveness of the LIM it is possible to use an additional bias winding, similar to that which was discussed earlier for the spindle-shaped variant. 
Let's calculate the magnetic field of this motor (Fig. 4). Here area 0 simulates the ferromagnetic core of the inductor, area 1 is the capsule, area 2 is air. There is a three-phase winding on the border between arias 0 and 1 . We assume that the dimensions of the inductor and the capsule in the $x$ and $y$ directions are infinitely large; the capsule acceleration occurs along the $x$ direction. equal to

Let's replace the three-phase winding by the current layer with the density

$$
j_{1 y}=j_{1}=J_{m} \cos \left(\omega_{1} t-\alpha x\right), \quad \alpha=\frac{\pi}{\tau}, \quad J_{m}=\frac{m \sqrt{2} \pi k_{\text {win }}}{p \tau} I,
$$

where $\tau$ is the pole pitch, $m$ is the number of phases, $w$ is the number of seriesconnected turns of the phase or the number of turns of one parallel branch, $I$ is the effective value of the phase current, $p$ is the number of pairs of poles, $k_{w i n}$ is the winding factor.

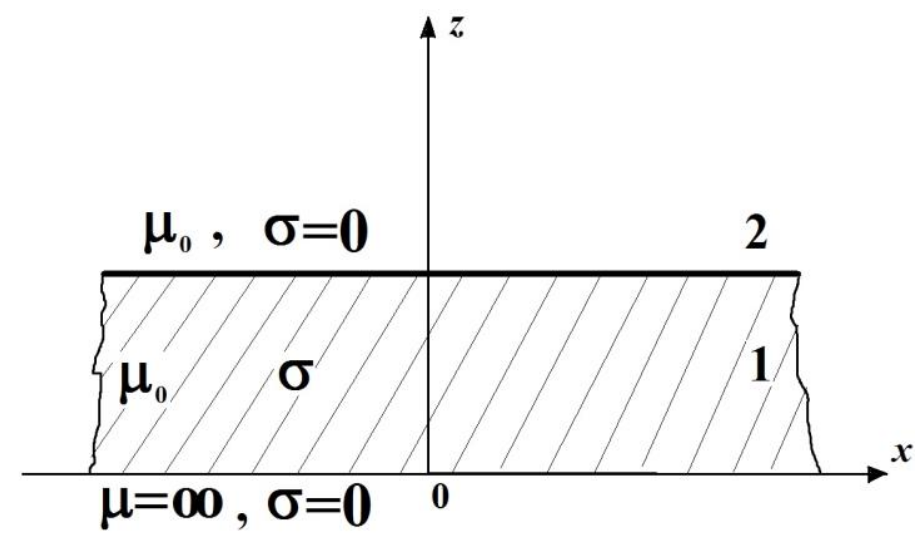

Fig. 4. The calculation scheme of LIM

The magnetic field in the capsule bottom is described by the equation

$$
\Delta \mathbf{A}_{1}-\mu_{0} \sigma \frac{\partial \mathbf{A}_{1}}{\partial t}+\mu_{0} \sigma\left(\mathbf{v} \times \operatorname{rot} \mathbf{A}_{1}\right)=0,
$$

here $\Delta$ is the Laplace operator; $\mathbf{A}_{\mathbf{1}}$ is the vector potential; $\sigma$ is the conductivity of the material of the capsule bottom; $\mu_{0}=4 \pi \times 10^{-7} \mathrm{H} / \mathrm{m} ; \mathbf{v}$ is the speed of the capsule.

Since $\mathbf{A}_{1}=\mathbf{j} A_{1}, \quad \mathbf{v}=\mathbf{i} u$, equation (2) takes the form

$$
\Delta A_{1}-\mu_{0} \sigma \frac{\partial A_{1}}{\partial t}-\mu_{0} \sigma u \frac{\partial A_{1}}{\partial x}=0 .
$$


In area 2 the field satisfies the Laplace equation

$$
\Delta \mathbf{A}_{2}=0 .
$$

Let's move to the complex images and suppose that

$$
A_{1}=\dot{A}_{1 m} \mathrm{e}^{i\left(\omega_{1} t-\alpha x\right)}, \quad A_{2}=\dot{A}_{2 m} \mathrm{e}^{i\left(\omega_{1} t-\alpha x\right)},
$$

$\dot{A}_{1 m}, \quad \dot{A}_{2 m}$ are the complex amplitudes. Then (3) and (4) can be written as follows

$$
\begin{gathered}
\frac{d^{2} \dot{A}_{1 m}}{d z^{2}}-\lambda^{2} \dot{A}_{1 m}=0, \\
\frac{d^{2} \dot{A}_{2 m}}{d z^{2}}-\alpha^{2} \dot{A}_{2 m}=0,
\end{gathered}
$$

The boundary conditions are: at $z=0$ we have $H_{x}=J_{m} \cos \left(\omega_{1} t-\alpha x\right)$,

at $z=\delta$

$$
\text { so }\left.\frac{\partial \dot{\mathrm{A}}_{1 m}}{\partial z}\right|_{z=0}=-\mu_{0} J_{m} \text {, }
$$

$$
\left[\dot{\mathrm{A}}_{m}\right]_{S_{12}}=0, \quad\left[\frac{\partial \dot{A}_{m}}{\partial z}\right]_{S_{12}}=0
$$

at $\mathrm{z}=\infty$

$$
\left.\dot{A}_{2 m}\right|_{z=\infty}=0,
$$

where $\lambda^{2}=\alpha^{2}(1+\mathrm{j} \varepsilon), \quad s=\frac{\omega_{1}-\omega_{2}}{\omega_{1}}, \quad \varepsilon=\frac{\mu_{0} \sigma s \omega_{1}}{\alpha^{2}}$, the parameter $\varepsilon$ plays the role of the magnetic Reynolds number; $\omega_{2}$ is the frequency corresponding to the capsule speed. From (5)-(7) it follows

$$
\begin{gathered}
\dot{A}_{1 m}=\mu_{0} J_{m} \dot{C}\left[(\lambda-\alpha) \mathrm{e}^{\lambda(z-\delta)}+(\lambda+\alpha) \mathrm{e}^{-\lambda(z-\delta)}\right], \quad \dot{A}_{2 m}=2 \mu_{0} J_{m} \lambda \dot{C} \mathrm{e}^{(\delta-z) \alpha}, \\
\dot{C}=C_{a}-i C_{w}=\frac{1}{\lambda\left[(\lambda+\alpha) \mathrm{e}^{\lambda \delta}-(\lambda-\alpha) \mathrm{e}^{-\lambda \delta}\right]} .
\end{gathered}
$$

Hence we shall find out the formulas for the magnetic induction $B_{x}, B_{y}$, the density of eddy currents $j_{y}$ in the capsule bottom 


$$
\begin{gathered}
B_{x}=\dot{B}_{m x} \mathrm{e}^{i\left(\omega_{1} t-\alpha x\right)}, \quad \dot{B}_{m x}=2 \mu_{0} J_{m} \lambda \dot{C}[\alpha \operatorname{ch} \lambda(z-\delta)-\lambda \operatorname{sh} \lambda(z-\delta)], \\
B_{z}=\dot{B}_{m z} \mathrm{e}^{i\left(\omega_{1} t-\alpha x\right)}, \quad \dot{B}_{m z}=-i 2 \mu_{0} J_{m} \alpha \dot{C}[\lambda \operatorname{ch} \lambda(z-\delta)-\alpha \operatorname{sh} \lambda(z-\delta)], \\
j_{y}=j_{m} \mathrm{e}^{i\left(\omega_{1} t-\alpha x\right)}, \quad j_{m}=-i 2 J_{m} \alpha^{2} \varepsilon \dot{C}[\lambda \operatorname{ch} \lambda(z-\delta)-\alpha \operatorname{sh} \lambda(z-\delta)]
\end{gathered}
$$

Let's find the stator magnetic field in area 1. Using (8), (9) and supposing $\sigma=0$ in them we receive

$$
B_{x}=\mu_{0} J_{m} \mathrm{e}^{-\alpha z+i\left(\omega_{1} t-\alpha x\right)}, \quad B_{z}=-i \mu_{0} J_{m} \mathrm{e}^{-\alpha z+i\left(\omega_{1} t-\alpha x\right)} .
$$

Let's define the electromagnetic forces acting to the capsule with the volume $V=l b d$, where $l$ is the length, $b$ is the width, $d$ is the thickness. The average values of these forces during the period of changing eddy currents are defined as follows:

for the propulsive force

$$
\begin{aligned}
F_{x}=\frac{k_{l} S}{2} \operatorname{Re} \int_{0}^{\delta} B_{m z}^{*} j_{m} d z & =\frac{1}{2} \mu_{0} J_{m}^{2} \alpha^{3} \varepsilon S C_{m}^{2} k_{l}\left[\frac{\lambda_{m}^{2}+\alpha^{2}}{\lambda_{a}} \operatorname{sh} 2 \lambda_{a} \delta+\frac{\lambda_{m}^{2}-\alpha^{2}}{\lambda_{w}} \sin 2 \lambda_{w} \delta+\right. \\
& \left.+2 \alpha\left(\operatorname{ch} 2 \lambda_{a} \delta-\cos 2 \lambda_{w} \delta\right)\right],
\end{aligned}
$$

where $k_{l}$ is the coefficient taking edge effects into account, $S=l b, B_{m x}^{*}$ and $B_{m z}^{*}$ are the conjugate complexes derived from (8) and (9); $j_{m}$ is the complex amplitude of eddy currents (10);

for the normal (levitating) force

$$
\begin{aligned}
F_{z}= & \frac{k_{l} S}{2} \operatorname{Re} \int_{0}^{\delta} B_{m x}^{*}=\frac{1}{2} \mu_{0} J_{m}^{2} \alpha^{2} \lambda_{m} \varepsilon S C_{m}^{2} k_{l}\left[\alpha \lambda_{m} \sin 2 \beta\left(\frac{\sin 2 \lambda_{w} \delta}{\lambda_{w}}-\frac{\operatorname{sh} 2 \lambda_{a} \delta}{\lambda_{a}}\right)+\right. \\
& \left.+\left(\lambda_{m}^{2}+\alpha^{2}\right) \sin \beta \cdot \frac{1-\operatorname{ch} 2 \lambda_{a} \delta}{\lambda_{a}}-\left(\lambda_{m}^{2}-\alpha^{2}\right) \cos \beta \cdot \frac{1-\cos 2 \lambda_{w} \delta}{\lambda_{w}}\right] .
\end{aligned}
$$

Here $C_{m}^{2}=C_{a}^{2}+C_{w}^{2}, \quad \lambda=\lambda_{a}+i \lambda_{w}=\lambda_{m} e^{i \beta}$.

If $\varepsilon\rangle>1$ then $\lambda \approx \alpha\left(\frac{\varepsilon}{2}\right)^{0,5} \cdot(1+i)$ So that $\lambda_{m}=\alpha \sqrt{\varepsilon}, \quad \lambda_{a}=\lambda_{w}=\alpha\left(\frac{\varepsilon}{2}\right)^{0,5}$, $\sin \beta=\cos \beta=\frac{1}{\sqrt{2}}$. Therefore at a large magnetic Reynolds number we obtain the following approximate formulas for the electromagnetic forces 


$$
\begin{gathered}
F_{x}=\mu_{0} J_{m}^{2} \alpha^{4} \varepsilon S C_{m}^{2} k_{l} \cdot \\
{\left[\left(\frac{\varepsilon}{2}\right)^{1 / 2}\left(\operatorname{sh} 2 \alpha\left(\frac{\varepsilon}{2}\right)^{1 / 2} \delta+\sin 2 \alpha\left(\frac{\varepsilon}{2}\right)^{1 / 2} \delta\right)+\operatorname{ch} 2 \alpha\left(\frac{\varepsilon}{2}\right)^{1 / 2} \delta-\cos 2 \alpha\left(\frac{\varepsilon}{2}\right)^{1 / 2} \delta\right]} \\
F_{z}=\mu_{0} J_{m}^{2} \alpha^{4} \varepsilon^{3 / 2} S C_{m}^{2} k_{l} \cdot \\
\cdot\left[\left(\frac{1}{2}\right)^{1 / 2} \sin \left(\alpha \varepsilon^{1 / 2} \delta\right)-\operatorname{sh}\left(\alpha \varepsilon^{1 / 2} \delta\right)+\frac{\varepsilon^{1 / 2}}{2}\left(\cos \left(\alpha \varepsilon^{1 / 2} \delta\right)-\operatorname{ch}\left(\alpha \varepsilon^{1 / 2} \delta\right)\right)\right]
\end{gathered}
$$

Let's consider the induction motor as a symmetrical three-phase device. We write the Kirchhoff equations for one phase

$$
\begin{aligned}
& \dot{U}_{1}=r_{1} \dot{I}_{1}+i x_{11} \dot{I}_{1}+i x_{12} \dot{I}_{2} \\
& 0=r_{2} \dot{I}_{2}+i x_{22} \dot{I}_{2}+i x_{12} \dot{I}_{1}
\end{aligned}
$$

here $r_{1}$ and $r_{2}$ are the active resistances of the primary and secondary circuits; $x_{11}$ and $x_{22}$ are the total self-inductive reactances of these circuits; $x_{12}$ is the mutual resistance. Eliminating the current $\dot{I}_{2}$ we receive

$$
\dot{U}_{1}=r_{1} \dot{I}_{1}+i x_{11} \dot{I}_{1}+\left(r_{\text {ins }}+i x_{\text {ins }}\right) \dot{I}_{1}
$$

where $r_{\text {ins }}$ and $x_{\text {ins }}$ are the insertion resistances equal to

$$
r_{\text {ins }}=\frac{x_{12}^{2} r_{2}}{r_{2}^{2}+x_{22}^{2}}, \quad x_{\text {ins }}=-\frac{x_{12}^{2} x_{22}}{r_{2}^{2}+x_{22}^{2}} \text {. }
$$

Multiplying (15) by the conjugate complex current $\stackrel{*}{I}_{1}$ we shall obtain the equation of power balance for one phase. In this equation the terms $r_{\text {ins }} I_{1}^{2}$ and $x_{\text {ins }} I_{1}^{2}$ mean, respectively, the active and reactive powers of one phase of the primary circuit transmitted to the secondary circuit. If you introduce the concept of electromagnetic power $\dot{S}_{\mathrm{EM}}\left(\dot{S}_{\mathrm{EM}}=P_{\mathrm{EMa}}+i Q_{\mathrm{EMw}}\right)$ into consideration then

$$
r_{\mathrm{ins}}=\frac{P_{\mathrm{EMa}}}{m I_{1}^{2}}, \quad x_{\mathrm{ins}}=\frac{Q_{\mathrm{EMw}}}{m I_{1}^{2}} .
$$

Thus the insertion resistances will be found if we know the electromagnetic power of the motor for some fixed value of stator current [11-16]. 
To calculate the LIM electromagnetic power let's multiply the first equation of (14) by $\stackrel{*}{I_{1}}$. Then we receive

$$
\dot{S}_{\mathrm{EM}}=-\dot{E}_{12} \stackrel{*}{I_{1}}
$$

where $\dot{E}_{12}=-i x_{12} \dot{I}_{2}$ is the effective value of the EMF induced in the primary circuit by the secondary field. This EMF is induced only by the $z$-component of the secondary field. Therefore, if we consider the electromagnetic processes in the capsule in the context of equations (14) we should take $B_{x}=0$ in (8) and (9) and consider that $B_{z}$ does not depend on $z$. In this regard as $\dot{B}_{m z}$ we take its value at $z=0$ multiplied by a coefficient $k_{\mathrm{B}}\left(k_{\mathrm{B}}<1\right)$, i.e.

$$
\dot{B}_{m z}=-i 2 \mu_{0} J_{m} \alpha k_{\mathrm{B}} \dot{C}(\lambda \operatorname{ch} \lambda \delta+\alpha \operatorname{sh} \alpha \delta) .
$$

Further we write (18) like

$$
\dot{S}_{\mathrm{EM}}=-\frac{k_{l}}{2} \int_{V} \dot{E}_{m 12}\left(k_{\mathrm{B}} J_{m}\right)^{2} d V
$$

where $\dot{E}_{m 12}=\dot{B}_{m z} \cdot 2 \tau f_{1}$ is the complex amplitude of the electric field strength which is corresponding to a magnetic field (19); $J_{m}$ is the amplitude of the current density defined by the formula (1); $k_{1}$ is the coefficient taking the edge effects into account. Then

$$
\dot{S}_{\mathrm{EM}}=P_{\mathrm{EMa}}+i Q_{\mathrm{EMw}}=i \mu_{0}\left(k_{\mathrm{B}} J_{m}\right)^{2} k_{l} \alpha \dot{C}(\lambda \operatorname{ch} \lambda \delta+\alpha \operatorname{sh} \alpha \delta) V 2 \tau f_{1} .
$$

Thus the formulas (17) and (21) at the known stator current $I_{1}$ allow us to find the insertion resistances ( $r_{\text {ins }}$ and $x_{\text {ins }}$ ). In addition from (21) we can obtain the propulsive force

$$
F_{\mathrm{x}}=\frac{1}{2 \tau f_{1}} \operatorname{Re} \dot{S}_{\mathrm{EM}}=\operatorname{Re}\left[i \mu_{0}\left(k_{\mathrm{B}} J_{m}\right)^{2} k_{l} \alpha \dot{C} V(\lambda \operatorname{ch} \lambda \delta+\alpha \operatorname{sh} \alpha \delta)\right]
$$

At the large magnetic Reynolds numbers as we have shown $\lambda=\alpha\left(\frac{\varepsilon}{2}\right)^{0,5}(1+i)$ and from (21) and (22) it follows

$$
\begin{aligned}
P_{\mathrm{EMa}}= & \mu_{0}\left(k_{\mathrm{B}} J_{m}\right)^{2} k_{l} \alpha V 2 \tau f_{1} \cdot\left\{C_{w}\left[\lambda_{0}\left(\cos \lambda_{0} \delta \operatorname{ch} \lambda_{0} \delta-\sin \lambda_{0} \delta \operatorname{shh} \lambda_{0} \delta\right)+\alpha \cos \lambda_{0} \delta \operatorname{sh} \lambda_{0} \delta\right]-\right. \\
& \left.-C_{a}\left[\lambda_{0}\left(\sin \lambda_{0} \delta \operatorname{sh} \lambda_{0} \delta+\cos \lambda_{0} \delta \operatorname{ch} \lambda_{0} \delta\right)+\alpha \sin \lambda_{0} \delta \operatorname{ch} \lambda_{0} \delta\right]\right\},
\end{aligned}
$$




$$
\begin{aligned}
Q_{\mathrm{EM} w}= & \mu_{0}\left(k_{\mathrm{B}} J_{m}\right)^{2} k_{l} \alpha V 2 \tau f_{1} \cdot\left\{C_{w}\left[\lambda_{0}\left(\cos \lambda_{0} \delta \operatorname{ch} \lambda_{0} \delta+\sin \lambda_{0} \delta \operatorname{sh} \lambda_{0} \delta\right)+\alpha \sin \lambda_{0} \delta \operatorname{ch} \lambda_{0} \delta\right]+\right. \\
\left.+C_{a}\left[\lambda_{0}\left(\cos \lambda_{0} \delta \operatorname{ch} \lambda_{0} \delta-\sin \lambda_{0} \delta \operatorname{sh} \lambda_{0} \delta\right)+\alpha \cos \lambda_{0} \delta \operatorname{sh} \lambda_{0} \delta\right]\right\}, & \\
F_{x}= & \mu_{0}\left(k_{\mathrm{B}} J_{m}\right)^{2} k_{l} \alpha V \cdot\left\{C_{w}\left[\lambda_{0}\left(\cos \lambda_{0} \delta \operatorname{ch} \lambda_{0} \delta-\sin \lambda_{0} \delta \operatorname{sh} \lambda_{0} \delta\right)+\alpha \cos \lambda_{0} \delta \operatorname{sh} \lambda_{0} \delta\right]-\right. \\
& \left.-C_{a}\left[\lambda_{0}\left(\cos \lambda_{0} \delta \operatorname{ch} \lambda_{0} \delta+\sin \lambda_{0} \delta \operatorname{sh} \lambda_{0} \delta\right)+\alpha \sin \lambda_{0} \delta \operatorname{ch} \lambda_{0} \delta\right]\right\} .
\end{aligned}
$$

The factor $k_{\mathrm{B}}$ is in the formulas for the electromagnetic power and propulsive forces (20)-(25). We can found it from the condition that the formulas (12) and (22) should give the same value of propulsive forces, though we used different approaches to receive them. Obviously it fully applies to the formulas (13) and (25). Thus the coefficient $k_{\mathrm{B}}$ is determined by one of the equations

$$
\begin{gathered}
k_{\mathrm{B}}^{2}=\frac{\varepsilon\left(\alpha C_{m}\right)^{2}}{2 \operatorname{Re}[i \delta \dot{C}(\lambda \operatorname{ch} \lambda \delta+\alpha \operatorname{sh} \lambda \delta)]} . \\
\cdot\left[\frac{\lambda_{m}^{2}+\alpha^{2}}{\lambda_{a}} \operatorname{sh} 2 \lambda_{a} \delta+\frac{\lambda_{m}^{2}-\alpha^{2}}{\lambda_{w}} \sin 2 \lambda_{w} \delta+2 \alpha\left(\operatorname{ch} 2 \lambda_{a} \delta-\cos 2 \lambda_{w} \delta\right)\right]
\end{gathered}
$$

at the arbitrary magnetic Reynolds numbers and

$$
\begin{gathered}
k_{\mathrm{B}}^{2}=\frac{\varepsilon \alpha^{3} C_{m}^{2}\left[\left(\frac{\varepsilon}{2}\right)^{1 / 2}\left(\operatorname{sh} 2 \alpha\left(\frac{\varepsilon}{2}\right)^{1 / 2} \delta+\sin 2 \alpha\left(\frac{\varepsilon}{2}\right)^{1 / 2} \delta\right)+\right.}{\delta\left\{C_{w}\left[\lambda_{0}\left(\cos \lambda_{0} \delta \operatorname{ch} \lambda_{0} \delta-\sin \lambda_{0} \delta \operatorname{sh} \lambda_{0} \delta\right)+\alpha \cos \lambda_{0} \delta \operatorname{sh} \lambda_{0} \delta\right]-\right.} \\
\left.+\operatorname{ch} 2 \alpha\left(\frac{\varepsilon}{2}\right)^{1 / 2} \delta-\cos 2 \alpha\left(\frac{\varepsilon}{2}\right)^{1 / 2} \delta\right] \\
\left.-C_{a}\left[\lambda_{0}\left(\cos \lambda_{0} \delta \operatorname{ch} \lambda_{0} \delta+\sin \lambda_{0} \delta \operatorname{sh} \lambda_{0} \delta\right)+\alpha \sin \lambda_{0} \delta \operatorname{ch} \lambda_{0} \delta\right]\right\}
\end{gathered}
$$

at the large magnetic Reynolds numbers.

Let's consider the electromagnetic motor parameters.

If we assume that the secondary magnitudes are reduced to the primary circuit in the equations (14) then the T-shaped equivalent circuit (Fig. 5) corresponds to them. In the scheme $x_{\mathrm{M} 1}$ is the main inductive reactance of the primary circuit; $x_{\sigma 1}$ is the inductive leakage resistance of the primary circuit ( $x_{\sigma 1}$ $\left.=x_{11}-x_{\mathrm{r} 1}\right) ; x_{\sigma^{2}}$ is the leakage inductive resistance of the secondary circuit $\left(x_{\sigma^{2}}=\right.$ $\left.x_{22}-x_{\mathrm{r} 1}\right) ; r_{1}$ and $r_{2}$ are the resistances of the circuits. All these parameters can be calculated by the usual methods for the theory of electrical machines, except for $x_{\sigma 2}$, and $r_{2}$. 


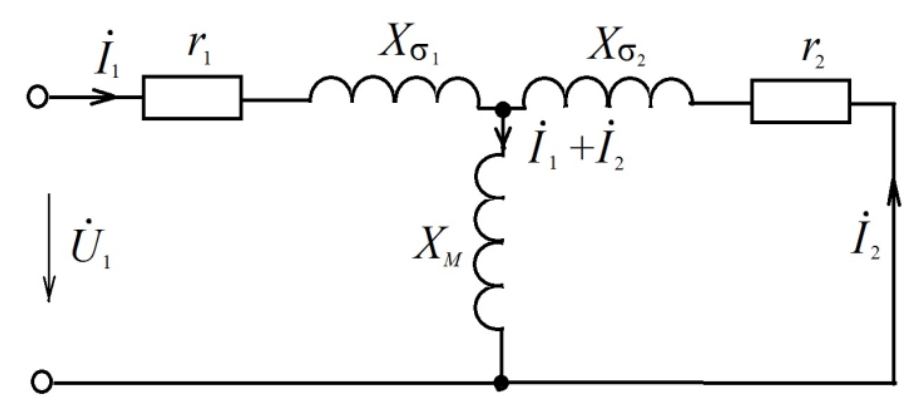

Fig. 5. The equivalent scheme

To calculate the main inductance $x_{\mathrm{r} 1}$ we introduced the coefficient $k_{l}=l / l_{s}$ into the common equation for this parameter, where $l$ is the capsule length, $l_{s}$ is the stator length

$$
x_{\Gamma 1}=\frac{\pi \sqrt{2} f_{1} w_{1} k_{\mathrm{o \sigma}} k_{l} \Phi_{1}}{I_{1}}
$$

Here $f_{1}$ is the frequency of the stator current; $w_{1}$ is the number of seriesconnected turns of the phase; $\Phi_{1}$ is the magnetic flux per pole due to the stator current. In accordance with (11) we assume the peak of the magnetic induction of the primary field in the capsule equal to $B_{1}=\mu_{0} J_{m} k_{\mathrm{B}}$, where $J_{m}$ is given by the formula (1) and $k_{\mathrm{B}}$ is given by one of the formulas (26) or (27). Let's denote

$$
k_{\mathrm{B}}=\frac{\tau}{\pi \delta^{\prime}},
$$

where $\delta^{\prime}$ is some effective clearance. Then we can write

$$
\Phi_{1}=\frac{2}{\pi} \cdot \frac{\mu_{0}}{\delta^{\prime}} \cdot 2 \tau b \cdot \frac{m \sqrt{2} \varpi_{1} k_{\mathrm{win}} k_{l}}{\pi p} I_{1}
$$

where $b$ is the capsule width. We have

$$
x_{\mathrm{M} 1}=\frac{4 \mu_{0} f_{1} 2 \tau b}{\pi \delta} \cdot \frac{m\left(\varpi_{1} k_{\mathrm{win}}\right)^{2} k_{l}}{p} .
$$

The calculation of the leakage field of a one-side stator is a separate task and needs some special consideration. Therefore let's limit by the approximate estimate of the corresponding parameter.

Let's define the total inductive reactance of the primary circuit $x_{11}$ as the sum of two components: the inductive stator reactance $x_{11}^{0}$ due to the primary 
field in the width of the inductor magnetic core and the inductive reactance $x_{\text {end }}$ of the leakage field in the end parts

$$
x_{11}=x_{11}^{0}+x_{\mathrm{\Omega}} .
$$

The component $x_{11}^{0}$ is the resistance of the whole stator winding calculated for the induction of the primary field on the stator surface. Therefore we receive the formula for $x_{11}^{0}$ from (29) supposing $\frac{\tau}{\pi \delta^{\prime}}=1$ and $k_{l}=1$ in it

$$
x_{11}^{0}=4 \mu_{0} f_{1} \cdot 2 b \cdot \frac{m\left(\varpi_{1} k_{\text {win }}\right)^{2}}{p} .
$$

We shall find the inductive reactance $x_{\text {end }}$ of the end part

$$
x_{\mathrm{n}}=4 \pi \mu_{0} f_{1} \varpi_{1}^{2} \frac{0,175-\frac{0,3 \delta^{\prime}}{\tau}}{p}\left(l_{\pi}-0,64 \tau\right),
$$

where $\delta^{\prime}$ is defined by the formula (29); $l_{\text {end }}$ is the average length of the end part of one side of the stator.

Thus we can calculate the approximate value of the inductive leakage reactance of the primary circuit $x_{\sigma 1}$ by the formula

$$
x_{\sigma 1}=4 \mu_{0} f_{1} \cdot 2 b \cdot \frac{m\left(\varpi_{1} k_{\mathrm{o} \sigma}\right)^{2}}{p}\left(1-\frac{\tau k_{l}}{\pi \delta^{\prime}}\right)+x_{\pi} .
$$

Here according to (28) $k_{\mathrm{B}}=\frac{\tau}{\pi \delta^{\prime}}$ but $k_{\mathrm{B}}<1$; in addition $k_{l}$ is a small value as the capsule length is usually significantly less than the stator length. Therefore we should expect that the inductive leakage reactance of the primary circuit $x_{\sigma 1}$ will be considerably bigger than the main inductive reactance of the same circuit. It determines the low energy efficiency and the low power factor of the motor. To improve them it's necessary to divide the stator into separate electrically independent sections.

We obtained the calculation formulas (17), (21), (23) and (25) for the insertion resistances $r_{\text {ins }}$ and $x_{\text {ins }}$. Knowing these parameters and having in mind that $x_{12}=x_{\mathrm{M} 1}$, we can find the secondary parameters using the equations (16)

$$
r_{2}=\frac{x_{\Gamma 1}^{2} r_{\mathrm{B}}}{r_{\mathrm{B}}^{2}+x_{\mathrm{B}}^{2}}, \quad x_{22}=-\frac{x_{\Gamma 1}^{2} x_{\mathrm{B}}}{r_{\mathrm{B}}^{2}+x_{\mathrm{B}}^{2}}
$$


and after the inductive leakage reactance $x_{2 \sigma}$ of the secondary circuit

$$
x_{2 \sigma}=x_{22}-x_{\Gamma 1}
$$

When we calculate the electromagnetic motor parameters it will be useful the information resulting from the ratio which establishes the connection between the magnetic induction $B_{m}$ of the resulting field in the capsule (at the slip $s_{m}$ ) and MMF of the stator winding. The fact is that with the specified maximum of the propulsive force $F_{m}$ we can consider that the value of $B_{m}$ is known. Thus we speak about the definition of MMS of the stator by the known value of $B_{m}$. We can take

$$
B_{m}=\left|\dot{B}_{m z}\right| z=0 \mid \cdot k_{\mathrm{B}}
$$

where $\dot{B}_{m z}$ is given by the formula (9). Therefore

$$
B_{m}=k_{\mathrm{B}} \cdot\left|2 \mu_{0} \alpha \dot{C}(\lambda \operatorname{ch} \lambda \delta+\alpha \operatorname{sh} \lambda \delta)\right| J_{m} .
$$

Now we can find the amplitude $J_{m}$ of the current density in the current sheet simulating the stator winding. But $J_{m}=\frac{\pi}{\tau} F$, where $F$ is MMF of the stator winding

$$
F=\frac{m \sqrt{2}}{\pi} \cdot \frac{\varpi_{1} k_{0 \sigma}}{p} I_{1} .
$$

In conclusion we give the equations characterizing the energy performance of LIM. The input power of LIM is equal

$$
\dot{S}_{1}=P_{1 \mathrm{a}}+i Q_{\mathrm{p}}=m \dot{U}_{1} \stackrel{*}{I_{1}}
$$

where the connection between $\dot{U}_{1}$ and $\dot{I}_{1}$ is given by the equation (15);

the efficiency is equal

$$
\eta=\frac{P_{\mathrm{EMa}}}{P_{\text {la }}}
$$

the power factor is 


$$
\cos \varphi=\frac{P_{1 \mathrm{a}}}{\left(P_{1 \mathrm{a}}^{2}+Q_{1 \mathrm{p}}^{2}\right)^{1 / 2}} .
$$

Thus we receive the main relations characterizing the electromechanical processes in the LIM in the form convenient for computational studies.

\section{CONCLUSION}

1. The creation of a pipeline transport with a rarefied medium in the pipe will require to solve the complex engineering problems. It will give a powerful incentive to the further development of the transport industry in Russia.

2. The construction of the vacuum-levitating transport in Russia is reasonable and justified economically but only among the densely populated centers, i.e. mainly in the European part of Russia.

3 . It is reasonable to use the lower pressure in the pipe (1.5-2 times in comparison with atmospheric pressure), i.e. to refuse the use of the technical vacuum. We can partially compensate the increase of the aerodynamic resistance by using the perforated covering of the capsule head part.

4. It is perspective to use a linear induction motor with the stator located on the pipe wall.

\section{БИБЛИОГРАФИЧЕСКИЙ СПИСОК / REFERENCES}

1. Патент РФ на полезную модель № 24670/ 20.08.02. Бюл. № 23. Ким К.К. Кузов головного вагона высокоскоростного поезда. Режим доступа: http://www1.fips.ru/fips_servl/fips_servlet. Дата обращения: 04.07.2018. [Patent RUS №24670/20.08.02. Byul. №23. Kim KK. Body of the head car of the high-speed train. Available from: http://www1.fips.ru/fips_servl/fips_servlet (In Russ.)].

2. Патент РФ на полезную модель № 147076/ 27.10.14. Бюл. № 30. Ким К.К., Титова Т.С. Трубопроводный транспорт. Режим доступа: http://www1.fips.ru/fips_servl/fips_servlet. Дата обращения: 04.07.2018. [Patent RUS №147076/ 27.10.14. Byul. № 30. Kim KK, Titova TS. Pipeline transport. Available from: http://www1.fips.ru/fips_servl/fips_servlet (In Russ.)].

3. Кузнецов А.А., Мешкова О.Б. Модернизация спектрального оборудования для диагностирования и ремонта подвижного состава // Транспорт Урала. - 2009. - № 2. - C. 86-90. [Kuznecov AA, Meshkova OB. Modernizaciya spektral'nogo oborudovaniya dlya diagnostirovaniya i remonta podvizhnogo sostava. Transport Urala. 2009;2:86-90. (In Russ.)].

4. Кузнецов А.А., Глазырин А.В. Оценка структурных параметров стали методом атомно-эмиссионной спектроскопии // Омский научный вестник. - 2012. - №3 (112). - C. 240-245. [Kuznecov AA, Glazyrin AV. Ocenka strukturnyh parametrov stali metodom atomno-ehmissionnoj spektroskopii. Omskij nauchnyj vestnik. 2012;3(112):240-245. (In Russ.)]. 
5. Кузнецов А.А. Комплексные методы диагностирования промышленных изделий и узлов подвижного состава средствами атомно-эмиссионной спектроскопии - М.: Спутник, 2005. - 198 с. [Kuznecov AA. Kompleksnye metody diagnostirovaniya promyshlennyh izdelij i uzlov podvizhnogo sostava sredstvami atomno-ehmissionnoj spektroskopii. Moscow: Sputnik; 2005. 198 p. (In Russ.)].

6. Иванов С.Н., Забоин В.Н., Кулаков В.В., Романов В.В. Электродинамические характеристики твердощеточных систем для сверхпроводящих униполярных машин // Известия вузов. Электромеханика. - 1984. - № 4. - С. 54-57. [Ivanov SN, Zaboin VN, Kulakov VA, Romanov VV. Elektrodinamicheskie kharakteristiki tverdoshchetochnykh sistem dlya sverkhprovodyashchikh unipolyarnykh mashin. Izvestia vuzov. Electromechanika. 1984;4:54-57. (In Russ.)].

7. Иванов С.Н. Использование электромеханических преобразователей в качестве устройств электронагрева // Научно-технические ведомости СПбГТУ. Основной выпуск. - 2008. - № 3. - С. 246-252. [Ivanov SN. Using the heat-generating electromechanical converters as a heater. The scientific and technical files of SPbGTU. 2008;3:246-252. (In Russ.)].

8. Иванов С.Н., Пащенко Ф.Ф., Амосов О.С. Синтез системы управления электромеханического преобразователя // Датчики и системы. - 2006. - № 8. - C. 18-24. [Ivanov SN, Pashenko FF, Amosov OS. The synthesis of the control system of electromechanical converters. Sensors \& Systems. 2006;8:18-24. (In Russ.)]

9. Иванов С.Н. Проектирование элементов электротехнических комплексов для систем отопления транспортного назначения // Известия Петербургского университета путей сообщения. - 2010. - Вып. 3. - С. 105-114. [Ivanov SN. The design of components of electrotecnical complexes for heating systems of the transport. Proceeding of Petersburg Transport University. 2010;3:105-114. (In Russ.)].

10. Иванов С.Н. Системы управления электротехническими устройствами для генерации тепловой энергии и транспортирования теплоносителя // Известия Петербургского университета путей сообщения. - 2010. - Вып. 3. - С. 249-257. [Ivanov S.N. The control systems of the electrotechnical devices for generating heat energy and transporting the heat-carrying agent. Proceeding of Petersburg Transport University. 2010;3:249-257. (In Russ.)].

11. Иванов С.Н., Еськова А.В., Уханов С.В. Информационное обеспечение доказательства адекватности математической модели электромеханического теплогенератора // Известия вузов. Северо-Кавказский регион. Технические науки. - 2008. - С. 77-79. [Ivanov SN, Eskova AV, Uhanov SV. Informacionnoe obespechenie dokazatelstva adekvatnosti matematicheskoj modeli ehlektromekhanicheskogo teplogeneratora. Izvestiya VUZov. Severo-Kavkazskij region. Tekhnicheskie nauki. 2008:77-79. (In Russ.)].

12. Амосов О.С., Амосова Л.Н., Иванов С.Н. Синтез оптимальных систем управления электромеханическим теплогенерирующим комплексом // Информатика и системы управления. - 2009. - №1 (19) - C. 73-83. [Amosov OS, Amosova LN, Ivanov SN. Sintez optimal'nyh sistem upravleniya ehlektromekhanicheskim teplogeneriruyushchim kompleksom. Informatika i sistemy pravleniya. 2009;1(19):7383. (In Russ.)].

13. Иванов С.Н., Скрипилев А.А. Эффективность надежности электроэнергетических систем // Ученые записки КнАГТУ. - 2016. - № III-1 (27). - C. 20-26. [Ivanov SN, Skripilev AA. Ehffektivnost' nadezhnosti ehlektroehnergeticheskih system. Uchenye zapiski KnAGTU. 2016;III-1(27):20-26. (In Russ.)]. 
14. Иванов С.Н. Эффективность электроэнергетического оборудования // XX Междунар. научно-техн. конф. «Приоритетные направления развития науки и технологии». - Тула, 2016. - С. 80-81. [Ivanov SN. Ehfffektivnost ehnergeticheskogo oborudovaniya. XX Mezhdunar. nauchno-tekhn. konf. "Prioritetnye napravleniya razvitiya nauki i tekhnologij”. (Conference proceedings) Tula, 2016. p. 80-81. (In Russ.)].

15. Есин П.А., Иванов С.Н., Шестопалько Д.К. Эффективность применения композитных материалов в электротехнических установках // Ученые записки КнАГТУ. - 2017. - № III-1 (31). - C. 14-18. [Esin PA, Ivanov SN, Shestopalko DK. Ehffektivnost primeneniya kompozitnyh materialov $\mathrm{V}$ ehlektrotekhnicheskih ustanovkah. Uchenye zapiski KnAGTU. 2017;III-1(31):14-18. (In Russ.)].

16. Амосов О.С., Голоколос Д.А., Иванов С.Н., Со Х. Особенности проектирования электромеханических преобразователей для комплексных систем безопасности // Известия вузов. Электромеханика. - 2017. - Вып. 60. - №. 5 (197). - С. 5-11. [Amosov OS, Golokolos DA, Ivanov SN, Co H. Features of design of Electromechanical converters for integrated security systems. Izvestia vuzov. Electromechanika. 2017;60(5/197):5-11 (In Russ.)].

\section{Information about the author:}

Konstantin K. Kim, Doctor of Technical Sciences, Professor; address: 190031, St. Petersburg, Moscow av., 9;

eLibrary SPIN: 3278-4938; ORCID: 0000-0001-7282-4429;

E-mail: kimkk@mail.ru

\section{Сведения об авторе:}

Ким Константин Константинович, доктор технических наук, профессор; адрес: 190031, Санкт-Петербург, Московский пр., 9;

eLibrary SPIN: 3278-4938; ORCID: 0000-0001-7282-4429;

E-mail: kimkk@mail.ru

\section{Цитировать:}

Ким К.К. Российский вариант транспортной системы «Нyperloop» // Транспортные системы и технологии. - 2018. - Т. 4. - № 2. - С. 73-91. doi: 10.17816/transsyst2018427391

\section{To cite this article:}

Kim KK. The Russian Version of the Transport System "Hyperloop". Transportation Systems and Technology. 2018;4(2):73-91. doi: 10.17816/transsyst20184273-91 